\title{
Striatal dopamine D2 receptors in tardive dyskinesia: PET study
}

\author{
J BLIN, ${ }^{*}$ J C BARON,* H CAMBON,* A M BONNET, $\dagger$ B DUBOIS, $\dagger$ C LOC'H, ${ }^{*}$ \\ B MAZIÈRE, * Y AGID† \\ From the Service Hospitalier Frederic Joliot, CEA, Departement de Biologie, Orsay, ${ }^{*}$ and Clinique de \\ Neurologie et de Neuropsychologie, INSERM U289 CHU Pitié-Salpêtrière, Paris, $\dagger$ France
}

SUMMARY The dopamine D2 receptors were investigated in vivo in eight neuroleptic-free patients with persistent tardive dyskinesia using positron emission tomography and 76Br-bromospiperone. The striatal receptor density, estimated by the striatum/cerebellum radioligand concentration ratio, was not elevated in patients as compared with age-matched controls but was positively correlated with the severity of orofacial dyskinesia assessed with the Abnormal Involuntary Movement Rating Scale. These results indicate that tardive dyskinesia is associated with normal levels of striatal D2 receptors but the severity of orofacial movements may depend on the relative density of striatal D2 receptors.

Tardive dyskinesia (TD) is a protracted, sometimes permanent, complication of long-term neuroleptic treatment, affecting $13 \%$ to $31 \%$ of treated schizophrenic patients. ${ }^{12}$ It is a distressing condition as the involuntary movements affect the orofacial musculature and often do not respond to therapy save for reintroduction or increased dosage of neuroleptics. There is no established preventive measure other than restricting prescription, and limiting both dosage and duration, of neuroleptic treatment as much as possible. $^{3}$

Brain dopamine receptor hypersensitivity is the most widely accepted hypothesis for the development of TD: it resembles levodopa-induced dyskinesia; it is both caused and controlled by dopaminergic antagonists and aggravated by dopaminergic agonists; during and following chronic neuroleptic treatment, rodents show increased behavioural responses to dopaminergic agonists with correlated increase in dopamine D2 receptor density in the striatum. ${ }^{4}$ Until now, however, no direct evidence for this role of striatal D2 receptors has been obtained in prospectively selected TD patients. We have evaluated striatal D2 receptors in TD patients in vivo using positron emission tomography (PET) and $76 \mathrm{Br}$-bromospiperone to investigate the following hypothesis: (1) the striatal D2 receptors are increased in TD, and (2) the D2 receptor density is correlated to the severity of TD.

Correspondence to: J C Baron, INSERM U320, BP 5027, 14021 Caen, Cedex, France.

Received 14 October 1988 and in revised form 18 February 1989 Accepted 2 May 1989

\section{Patients and methods}

Eight dyskinetic patients were studied after giving informed consent (table 1). The eight TD patients ( 7 women and 1 man, mean age 64.3 years, SD 4.7$)$ were compared with eight agematched controls ( 3 women and 5 men, mean age 63.5, SD 2.6). The diagnosis of TD was established when abnormal involuntary movements (AIMS) (of a choreic nature), without other neurological abnormalities, had been permanent for the past 3 months, affecting in all cases the oro-linguofacial area and sometimes also the limbs or trunk, and had begun following a minimum of 3 months of exposure to neuroleptics, persisting at least 9 days after withdrawal of the neuroleptics (the type of which not being relevant). Neuroleptics had been prescribed, sometimes for many years, by general practitioners for reasons not always clear, particularly in the six chronically depressed patients. The characteristics of dyskinesia and the plasma concentration of prolactin (as an index of neuroleptic medication) were estimated at the time of PET study. The severity of dyskinesia was scored using the Abnormal Involuntary Movement Rating Scale ${ }^{56}$ from 0 (none) to 4 (maximal) for each of the four items describing facial and oral movements (orofacial AIMs score), two items describing limb movements, and the single item for trunk movements. All items combined defined a global AIMs score. The characteristics of neuroleptic treatment (type of drug, duration of treatment and duration of neuroleptic withdrawal before PET study) were recorded.

The dopaminergic D2 receptors were studied by PET and tracer amounts of $76 \mathrm{Br}$-bromospiperone (76Br-BSP), a specific high-affinity D2 antagonist. ${ }^{78}$ The radioligand was injected intravenously as a bolus $(1 \cdot 25, \mathrm{SD} 0.15 \mathrm{mCi}, 27, \mathrm{SD}$ $5.7 \mathrm{pmole} / \mathrm{kg}$ ). The studies were done on the four rings TTVO1 LETI time-of-flight positron camera. The subjects were carefully positioned according to the PET atlas of dopamine receptors ${ }^{9}$ so that the lowest slice included the 
Table 1 Characteristics of patients with tardive dyskinesia

\begin{tabular}{|c|c|c|c|c|c|c|c|c|c|c|}
\hline \multirow[b]{3}{*}{ Patient } & \multirow[b]{3}{*}{$\begin{array}{l}\text { Age } \\
\text { (years) }\end{array}$} & \multirow[b]{3}{*}{ Sex } & \multirow{3}{*}{$\begin{array}{l}\text { Psychiatric } \\
\text { condition }\end{array}$} & \multirow{2}{*}{\multicolumn{3}{|c|}{ Neuroleptics }} & \multicolumn{3}{|c|}{ Dyskinesia } & \multirow[b]{3}{*}{$\begin{array}{l}\text { Prolactin } \\
(\mathrm{ng} / \mathrm{ml})\end{array}$} \\
\hline & & & & & & & \multicolumn{2}{|c|}{ AIMS score } & \multirow[b]{2}{*}{$\begin{array}{l}\text { Duration } \\
\text { (months) }\end{array}$} & \\
\hline & & & & Type & $\begin{array}{l}\text { Duration } \\
\text { (years) }\end{array}$ & $\begin{array}{l}\text { Withdrawal } \\
\text { (days) }\end{array}$ & $O F$ & $G$ & & \\
\hline $\begin{array}{l}1 \\
2 \\
3 \\
4 \\
5 \\
6 \\
7 \\
8\end{array}$ & $\begin{array}{l}56 \\
63 \\
80 \\
53 \\
65 \\
85 \\
45 \\
67\end{array}$ & $\begin{array}{l}\mathrm{F} \\
\mathrm{M} \\
\mathrm{F} \\
\mathrm{F} \\
\mathrm{F} \\
\mathrm{F} \\
\mathrm{F} \\
\mathrm{F}\end{array}$ & $\begin{array}{l}\text { Depression } \\
\text { Depression } \\
\text { Depression } \\
\text { Depression } \\
\text { Depression } \\
\text { Dementia } \\
\text { Depression } \\
\text { Delirium }\end{array}$ & $\begin{array}{l}\text { PTZ } \\
\text { BZM } \\
\text { BZM } \\
\text { PTZ+ BTP } \\
\text { PTZ } \\
\text { BTP } \\
\text { PTZ+ BTP } \\
\text { BTP }\end{array}$ & $\begin{array}{r}23 \\
9 \\
3 \\
9 \\
3 \\
1 \\
25 \\
7\end{array}$ & $\begin{array}{r}70 \\
9 \\
9 \\
19 \\
32 \\
60 \\
60 \\
21\end{array}$ & $\begin{array}{r}18 \\
4 \\
13 \\
3 \\
8 \\
4 \\
7 \\
6\end{array}$ & $\begin{array}{r}10 \\
6 \\
16 \\
9 \\
8 \\
5 \\
9 \\
11\end{array}$ & $\begin{array}{r}17 \\
3 \\
12 \\
48 \\
5 \\
6 \\
3 \\
12\end{array}$ & $\begin{array}{l}4 \\
2 \\
4 \\
1 \\
1 \\
3 \\
4 \\
\end{array}$ \\
\hline
\end{tabular}

PTZ = phenothiazines; BZM = benzamides; $B$ TP = butyrophenones.

AIMS score: Abnormal Involuntary Movements Score, $\mathrm{OF}=$ orofacial score; $\mathbf{G}=$ global score (orofacial + limbs + trunk scores).

cerebellar hemispheres $(10 \mathrm{~mm}$ above and parallel to the orbitomeatal (OM) plane) and the third slice encompassed the striatum ( $40 \mathrm{~mm}$ above the $\mathrm{OM}$ plane). Attenuation correction was performed using a $68 \mathrm{Ga}-68 \mathrm{Ge}$ transmission scan. Five minutes after $76 \mathrm{Br}-\mathrm{BSP}$ injection a $15 \mathrm{~min}$ acquisition scan was started. A late 30 min acquisition scan was obtained 4.5 hours after injection. ${ }^{810}$ Accurate subject repositioning was achieved by using crossed laser beams projected on several ink marks drawn on the patient's face at the time of the early scan. All patients included in this study were able to hold the head still during PET scanning. This PET procedure has been approved by the local Ethical Committee.

The relative radioactive brain concentrations (in percentage of administered dose per $\mathrm{ml}$ of brain) were determined by one investigator blind to the condition of subjects (patients or controls) using regions of interest (ROIs) positioned on the 4.5 hrs PET images on which the striatum and the cerebellum were the most clearly delineated. ${ }^{10}$ One circular ROI $\left(9 \mathrm{~cm}^{2}\right)$ was positioned on each cerebellar hemisphere, and the striatal ROIs were automatically defined by a computer-generated $80 \%$ isocontour. ${ }^{10}$ These ROIs were then reproduced onto the early PET images. The striatal and the cerebellar values used in further analysis were the average of the right and left values. Using the $4.5 \mathrm{hr}$ data, the striatum-cerebellum ratio was then calculated. (This ratio, obtained later after ligand administration, provides a normalised index of specific binding of 76Br-BSP to the striatal $\mathrm{D} 2$ receptors because in the cerebellum the radioligand is only in the free and non-specifically bound forms, while in striatum it is also in the specifically-bound form ( $>95 \%$ to the D2 receptors; see refs 7 and 10 for discussion). During PET data acquisition, whole-blood relative radioactive concentrations were also obtained from venous sampling.

Using the above procedure the striatum/cerebellum ratio (S/C) was measured in 28 control subjects from 18 to 76 years of age. The linear regression of $\mathrm{S} / \mathrm{C}$ on age in the 28 controls was significant $(\mathrm{r}=0.046, \mathrm{p}<0.05)$, according to the following relationship: $\mathrm{S} / \mathrm{C}=2.222-0.006$ age $(\mathrm{yr})$; in the eight TD patients, the relationship was $S / C=2.404-0.010$ age $(y r)(r=0 \cdot 51, N S)$, and neither slope nor intercept were significantly different from that found in controls; this allowed pooling controls and patients $(\mathrm{N}=36)$ for linear regression, which was: $\mathrm{S} / \mathrm{C}=2.264-0.007$ years, $\mathrm{r}=0.54, \mathrm{p}$ $<0.001$. According to this relationship the $\mathrm{S} / \mathrm{C}$ ratio was normalised for each control and TD patient to the uniform age of 65 years (S/C65) using the equation $\mathrm{S} / \mathrm{C} 65=\mathrm{S} / \mathrm{Cm}-$ $0.007(65-\mathrm{A})$, where $\mathrm{S} / \mathrm{Cm}$ is the $\mathrm{S} / \mathrm{C}$ actually measured and $A$ is the actual age of the subject (in years). There was no significant difference in the $\mathrm{S} / \mathrm{C} 65$ value between male $(n=23)$ and female $(n=5)$ controls (mean, SD, 1.775, 0.151 and $1.966,0.337$, respectively). Statistical analysis used nonparametric tests (Mann-Whitney U test and Spearman rank correlation).

\section{Results}

Positron Emission Tomography data (tables 2 and 3) The individual PET data of the eight TD patients are shown on table 2. Table 3 shows the means for TD patients compared with eight age-matched controls extracted from the control group. The concentrations of 76Br-BSP (expressed in \% of injected dose/litre) were similar in TD and control subjects for whole blood at $\mathrm{t}=5 \mathrm{hr}$ after injection, cerebellum on early images, cerebellum on the $4.5 \mathrm{hr}$ images, and striatum at $4.5 \mathrm{hr}$. The $\mathrm{S} / \mathrm{C}$ ratios of the eight TD patients fell within the age-related spread of control values (fig 1). Neither the S/C nor the S/C 65 ratios differed significantly between dyskinetic patients and controls although the distribution of values tended to be higher in TD patients. The amount of administered radioligand was not significantly different between patients and controls.

\section{Correlations between Positron Emission Tomography and clinical data}

Neither the duration of neuroleptic treatment nor that of neuroleptic withdrawal was correlated with the S/C ratio, the $S / C 65$ ratio, the severity of orofacial or global dyskinesia, or the prolactinemia.

The severity of dyskinesia was correlated neither to age of patients nor to the cerebellar concentration of 76Br-BSP $4.5 \mathrm{hr}$ after injection (table 4). The AIMS global score showed no significant correlation with striatum $4.5 \mathrm{hr}$ radioactive concentration although the latter correlated positively with the severity of orofacial dyskinesia $(p=0.002)$. 
Table 2 Positron emission tomography data of the 8 dyskinetic patients

\begin{tabular}{|c|c|c|c|c|c|c|c|}
\hline \multirow[b]{3}{*}{ Patient } & \multicolumn{2}{|c|}{ 76Br-Bromospiperone } & & & \multirow{3}{*}{$\begin{array}{l}\text { Striatum } \\
(\% I D / L) \\
t=4.5 \mathrm{hr}\end{array}$} & \multirow[b]{3}{*}{$S / C$} & \multirow[b]{3}{*}{$S / C 65$} \\
\hline & \multirow{2}{*}{$\begin{array}{l}\text { Dose } \\
\text { (pmol/kg) }\end{array}$} & \multirow{2}{*}{$\begin{array}{l}\text { Blood } \\
t=5 \mathrm{hr} \\
(\% \mathrm{ID} / L)\end{array}$} & \multicolumn{2}{|c|}{ Cerebellum (\% ID/L) } & & & \\
\hline & & & $t=5 \min$ & $t=4.5 \mathrm{hr}$ & & & \\
\hline $\begin{array}{l}1 \\
2 \\
3 \\
4 \\
5 \\
6 \\
7 \\
8\end{array}$ & $\begin{array}{l}58.0 \\
10.7 \\
28.4 \\
18.2 \\
34.8 \\
36.9 \\
17.0 \\
11.8\end{array}$ & $\begin{array}{l}0.44 \\
0.35 \\
0.65 \\
- \\
0.62 \\
0.40 \\
0.56 \\
0.96\end{array}$ & $\begin{array}{l}1.316 \\
1.148 \\
1.405 \\
0.480 \\
1.229 \\
2.067 \\
1.077 \\
0.747\end{array}$ & $\begin{array}{l}1.328 \\
1.020 \\
1.457 \\
0.936 \\
1.144 \\
1.590 \\
1.099 \\
1.077\end{array}$ & $\begin{array}{l}2 \cdot 574 \\
1 \cdot 819 \\
2 \cdot 760 \\
1.490 \\
2 \cdot 314 \\
1.995 \\
2 \cdot 184 \\
1 \cdot 710\end{array}$ & $\begin{array}{l}1.938 \\
1.783 \\
1.894 \\
1.592 \\
2.023 \\
1.255 \\
1.987 \\
1.588\end{array}$ & $\begin{array}{l}1.875 \\
1.769 \\
1.999 \\
1.508 \\
2.023 \\
1.395 \\
1.847 \\
1.602\end{array}$ \\
\hline
\end{tabular}

$\%$ ID/L: percentage of injected dose of 76Br-BSP per litre of tissue.

S/C: Striatum cerebellum ratio.

S/C 65: 65 years age-adjusted S/C ratio.

Table 3 Positron emission tomography data in tardive dyskinesia patients and controls

\begin{tabular}{|c|c|c|}
\hline & $\begin{array}{l}\text { Tardive } \\
\text { dyskinesia } \\
(n=8) \\
(\text { mean, SEM) }\end{array}$ & $\begin{array}{l}\text { Controls } \\
(n=8) \\
(\text { mean, SEM })\end{array}$ \\
\hline $\begin{array}{l}\text { Age (years) } \\
76 \mathrm{Br}-\mathrm{BSP} \text { dose }(\mathrm{pmol} / \mathrm{kg}) \\
\text { Cerebellum } \mathrm{t}=5 \mathrm{~min}(\% \text { ID } / \mathrm{L}) \\
\text { Blood } \mathrm{t}=5 \mathrm{hr}(\% \text { ID } / \mathrm{L}) \\
\text { Striatum } \mathrm{t}=4.5 \mathrm{hr}(\% \text { ID } / \mathrm{L}) \\
\text { Cerebellum } \mathrm{t}=4.5 \mathrm{hr}(\% \text { ID } / \mathrm{L}) \\
\text { S } / \mathrm{C}=4.5 \mathrm{hr} \\
\mathrm{S} / \mathrm{C} 65 \mathrm{t}=4.5 \mathrm{hr}\end{array}$ & $\begin{array}{l}64 \cdot 3,4 \cdot 7 \\
27 \cdot 0,5 \cdot 7 \\
1 \cdot 184,0 \cdot 167 \\
0 \cdot 568,0 \cdot 078 \\
2 \cdot 106,0 \cdot 154 \\
1 \cdot 206,0 \cdot 081 \\
1 \cdot 757,0.093 \\
1 \cdot 753,0.082\end{array}$ & $\begin{array}{l}63 \cdot 8,2 \cdot 6 \\
44 \cdot 2,14 \cdot 0 \\
1 \cdot 211,0 \cdot 097 \\
0 \cdot 474,0 \cdot 048 \\
1 \cdot 914,0 \cdot 139 \\
1 \cdot 142,0 \cdot 088 \\
1 \cdot 698,0 \cdot 085 \\
1 \cdot 689,0.082\end{array}$ \\
\hline
\end{tabular}

Same abbreviations as in table 2.

No significant difference for any variable shown.

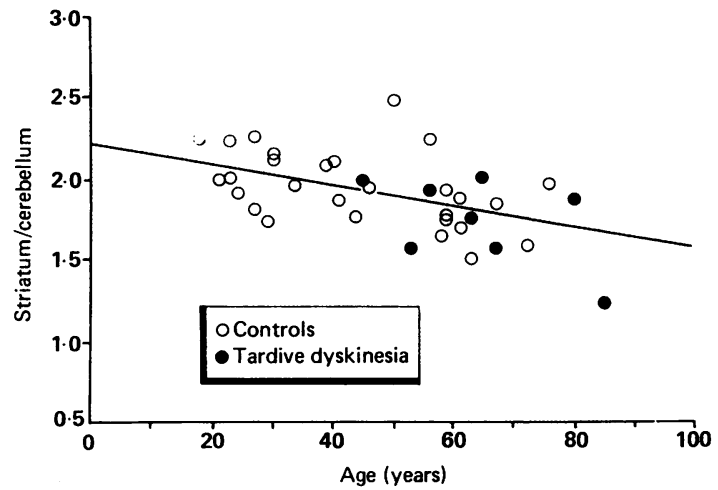

Fig 1 The striatum-to-cerebellum $(S / C) 76 B r-$

bromospiperone concentration ratio, an index of striatal dopaminergic D2 receptor density, is shown as a function of age in 28 control subjects and 8 tardive dyskinesia (TD) patients. There is no difference between controls and patients in the linear regression of $S / C$ on age. In all subjects the $S / C$ ratio decreases significantly $(p<0.001)$ with age according to the linear correlation $S / C=2.264-0.007 \mathrm{yr}$. The $S / C$ ratios of TD patients are distributed within the range of control subjects' values.
Table 4 Correlations with severity of dyskinesia

\begin{tabular}{|c|c|c|c|c|}
\hline & \multicolumn{2}{|c|}{$\begin{array}{l}\text { Global } \\
\text { AIMS score }\end{array}$} & \multicolumn{2}{|c|}{$\begin{array}{l}\text { Orofacial } \\
\text { AIMS score }\end{array}$} \\
\hline & $r$ & $p$ & $r$ & $p$ \\
\hline $\begin{array}{l}\text { Age } \\
\text { Cerebellum } \mathrm{t}=4.5 \mathrm{hr}(\% \text { ID/L) } \\
\text { Striatum } \mathrm{t}=4.5 \mathrm{hr}(\% \mathrm{ID} / \mathrm{L}) \\
\text { S/C } \\
\text { S/C } 65\end{array}$ & $\begin{array}{l}0.036 \\
0.012 \\
0.311 \\
0 \cdot 144 \\
0 \cdot 371\end{array}$ & $\begin{array}{l}\text { ns } \\
\text { ns } \\
\text { ns } \\
\text { ns } \\
\text { ns }\end{array}$ & $\begin{array}{l}0.169 \\
0.566 \\
0.916 \\
0.663 \\
0.880\end{array}$ & $\begin{array}{l}\text { ns } \\
\text { ns } \\
0.002 \\
0.07 \\
0.004\end{array}$ \\
\hline
\end{tabular}

See legends table 2.

The $\mathrm{S} / \mathrm{C}$ ratio was not significantly correlated with the severity of global dyskinesia and fell short of statistical significance with the severity of orofacialo dyskinesia $(r=+0.663, p=0.07)$. However, as individual age of patients interferes notably with the raw $\mathbf{S} / \mathrm{C}$, these linear regressions were also computed using the $\mathrm{S} / \mathrm{C} 65$ ratio, which is designed to cancel such

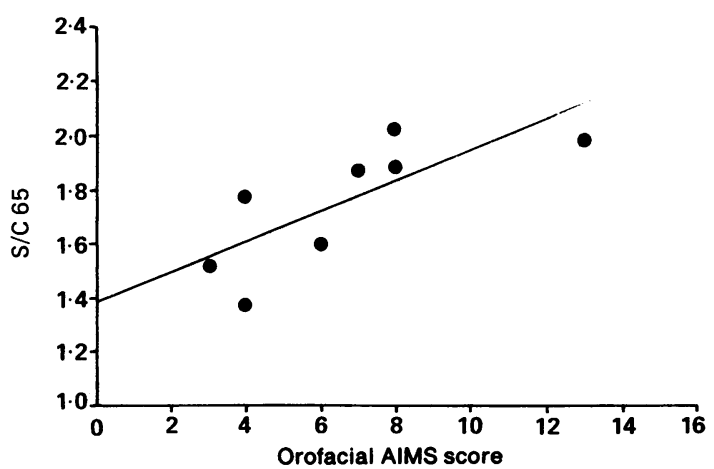

Fig 2 Graph showing the positive linear correlation between severity of orofacial dyskinesia (assessed in 8 patients with the Abnormal Involuntary Movement Rating Scale) and age adjusted striatum/cerebellum ratio (S/C65) suggesting an association between tardive dyskinesia and striatal D2 receptor density. The regression line was: $S / C 65=1 \cdot 389+$ $0.055^{*}$ AIMS score, $r=0.880, p=0.004$. 
age effects (see Methods). The S/C 65 ratio was not significantly correlated with the global AIMS score but was positively correlated with the orofacial AIMS score $(r=+0 \cdot 880, p=0 \cdot 004$, fig 2$)$.

\section{Discussion}

In order to select a clinically uniform sample of patients, stringent diagnostic criteria for TD were used in this study. ${ }^{11-14}$ Those should exclude patients with spontaneous or non-neuroleptic related dyskinesias, purely limb-truncal TD, symptomatic dyskinesia (such as Huntington's disease), psychogenic abnormal movements, or schizophrenic stereotypes.

Patients were investigated after neuroleptic withdrawal for at least 9 days. This interval was considered long enough to allow essentially complete washout of neuroleptics from their striatal binding sites, as demonstrated in a recent PET study using the same radioligand and the same methodology.$^{15}$ No correlation was found between the specific binding to D2 receptors (evaluated by the $\mathrm{S} / \mathrm{C}$ ratio), the severity of TD (quantitated by the AIMs scale) or the plasma concentration of Prolactin in TD patients, and the duration of neuroleptic withdrawal. This suggests that the delay of 9 days was sufficient and that this factor did not influence the present data to any measurable extent.

We found no significant difference between patients and age-matched controls for the $\mathrm{S} / \mathrm{C}$ ratio (table 3 ). Since there was no difference between patients and controls in blood and cerebellar tracer concentrations at 4.5 hours post-injection (indicating comparable free and non-specifically bound radioligand) as well as in the amount of administered radioligand (table 3 ), the lack of difference in the $\mathrm{S} / \mathrm{C}$ ratio of patients and controls suggests similar specifically-bound fraction. Because of the very small amount of radioligand administered it is assumed that $76 \mathrm{Br}-\mathrm{BSP}$ is $>95 \%$ bound to dopaminergic D2 receptors in striatum in vivo, as shown by displacement studies in rats. ${ }^{7}$ In these conditions where receptor occupation is very low, and assuming unchanged receptor affinity, the $\mathrm{S} / \mathrm{C}$ ratio reliably reflects the dopaminergic $\mathrm{D} 2$ receptor density. Also, the lack of difference in early $76 \mathrm{Br}-$ BSP relative concentration in cerebellum (table 3) suggests similar initial entry in brain. It must be emphasised here that delaying PET imaging until 4.5$5 \mathrm{hr}$ after injection of the radioligand allows a state to be reached where the influence of factors which control the initial access of radioligand in the brain on the specifically bound fraction (for example, blood flow) should have become negligible,${ }^{810}$ while labelled metabolites of $76 \mathrm{Br}-\mathrm{BSP}$ in striatum are still less than $5 \%$ of total radioactivity (unpublished data from rat studies in our institute). In the case of another radioligand for PET investigations, recent simulation studies have demonstrated the validity of the ratiomethod as an index of receptor density within reasonable changes both in $\mathrm{Bmax} / \mathrm{Kd}$ ratio and in regional cerebral blood flow. ${ }^{16}$

These data therefore suggest that the density of D2 receptors in striatum is not elevated in tardive dyskinesia. There is no other in vivo study of brain D2 receptors in TD to allow comparison with these results. The two relevant necropsy studies (both retrospective) are that of Crow et al ${ }^{17}$ who reported that "striatal spiperone binding was not significantly different between schizophrenic patients with and without movement disorders" and of Kornhuber et $a l^{18}$ who found no increase in striatal D2 receptors in five schizophrenic patients with orofacial TD as compared with TD-free schizophrenics. Our finding is also consistent with the present-day criticism of the hypothesis of increased D2 receptors density in TD. ${ }^{19}$ For example, Rupniak et $a l^{20}$ reported that if the AIMS induced by chronic neuroleptic administration in rodents are initially associated with an increased D2 receptor density, they, however, tend to persist despite a return to normal receptor values. In rats with spontaneous orofacial dyskinesia, the prevalence of this movement disorder is increased by chronic neuroleptic treatment as well as by age but there is no significant change in striatal dopaminergic receptors. ${ }^{21}$ Also, the incidence of both spontaneous and neuroleptic-induced orofacial dyskinesia in humans is clearly accentuated by ageing ${ }^{22}$ despite the wellestablished age-related decrease in D2 striatal receptor density. ${ }^{23-27}$ Recent theories implicating the striatal GABAergic and cholinergic systems have appeared as substitutes for the dopaminergic hypothesis. ${ }^{28}$

Although this study would tend to disprove our first hypothesis (elevated striatal D2 receptor density), we found a significant positive correlation between the age-adjusted S/C 65 ratio and the orofacial AIMS score (fig 3) (the $\mathrm{S} / \mathrm{C}$ ratio, which is not normalised for age, was close to being statistically significantly correlated to the orofacial AIMS score), in agreement with our second hypothesis that the severity of AIMS may be a function of the striatal D2 receptors density. The apparent discrepancy between the lack of significant difference in mean S/C 65 ratio between patients and controls, and the significant correlation between the individual S/C 65 ratio values and the severity of orofacial AIMS may seem surprising. Although it may reflect chance findings, it must be emphasised that the $\mathrm{S} / \mathrm{C}$ ratio measured according to our method ${ }^{1024}$ is highly sensitive to the loss of striatal D2 receptors demonstrated at necropsy in ageing 22.3 (see also fig 1) and also in progressive supranuclear palsy, ${ }^{1024}$ and reliably estimates the occupancy of striatal D2 receptors by orally-given neuroleptics. ${ }^{15}$ 
Hence the variance of the $S / C$ ratio observed both in controls and in TD patients may not only reflect methodological errors, but also carry physiological information. Our findings therefore would fit the hypothesis that TD is associated with a relative dopaminergic striatal hypersensitivity disrupting the balance among the postsynaptic types of DA receptors, between the pre- and the post-synaptic DA systems, or between the DA and the cholinergic, ${ }^{29}$ noradrenergic ${ }^{30}$ or GABAergic neurons in striatum. ${ }^{31-}$ ${ }^{33}$ Finally, the fact that the orofacial, but not the global AIMS score, was correlated with the S/C 65 value would fit recent clinical and pharmacological observations suggesting a different pathophysiology for orofacial and for limb-truncal TD. ${ }^{34}$ Alternatively, the scoring of the dyskinesia by the AIMS scale may be more accurate for orofacial than for peripheral movements.

\section{References}

1 Guy W, Ban TA, Wilson WH. An international survey of tardive dyskinesia. Neuro-Psychopharmacol Biol Psychiat 1985;9: 401-5.

2 Robinson ADT, McGreadie RG. The nightsdale schizophrenia survey. V. Follow-up of tardive dyskinesia at 3.5 years. $\mathrm{Br} \mathrm{J}$ Psychiatry 1986;149:621-3.

3 Tanner CM, Klawans HL. Tardive dyskinesia: Prevention and treatment. Clin Pharmacol 1986;9(suppl 2):S76-S84.

4 Burt DR, Creese I, Snyder SH. Antischizophrenic drugs: chronic treatment elevates dopamine receptor binding in brain. Science 1977;196:326-8.

5 Abnormal Involuntary Movement Scale (AIMS). Washington, DC, Alcohol, Drug Abuse, and Mental Health Administration, Department of Health, Education and Welfare, 1974.

6 United States Department of Health, Education and Welfare. Abnormal Involuntary Movement Scale (AIMS). In: Guy W, ed. ECDEU Assessment Manual for Psychopharmacology. Rockville: US Department of Health, 1976:534-7.

7 Mazière M, Loc'h C, Hantraye P, et al. 76-Br-Bromospiperone: A new tool for quantitative in-vivo imaging of neuroleptic receptors. Life Sci 1984;35:1349-56.

8 Mazière M, Loc'h C, Baron JC, et al. In vivo quantitative imaging of dopamine receptors in human brain using positron emission tomography and (76Br)Bromospiperone. Eur J Pharmacol 1985;114:267-72.

9 Inoue Y, Wagner HN, Wong DF, et al. Atlas of dopamine receptor images (PET) of the human brain. J Comput Assist Tomogr 1985;9:129-40.

10 Baron JC, Mazière M, Loc'h C, et al. Loss of striatal [76Br]Bromospiperone binding sites demonstrated by positron tomography in progressive supranuclear palsy. $J$ Cereb Blood Flow Met 1986;6:131-6.

11 Marsden CD, Tarsy D, Baldessarini RJ. Spontaneous and druginduced movement disorders in psychotic patients. In: Benson DF, Blumer D, eds. Psychiatric Aspects of Neurologic Disease. New York: Grune and Stratton, 1975:219-65.

12 Baldessarini RJ, Cole JO, Davis JM, et al. Tardive dyskinesia: Summary of a task force report of the American psychiatric association. Am J Psychiatry 1980;137:1163-72.

13 Schooler NR, Kane JM. Research diagnoses for tardive dyskinesia. Arch Gen Psychiatry 1982;39:486-7.

14 Tarsy D. Tardive dyskinesia. Ann Rev Med 1984;35:605-23.
15 Cambon H, Baron JC, Boulenger JP, Loc'h C, Zarifian E, Mazière B. In vivo assay for neuroleptic receptor binding in the striatum. Positron Tomography in humans. Br J Psychiatry 1987;151:824-30.

16 Frost JJ, Mayberg HS, Fisher RS, et al. Mu-opiate receptors measured by positron emission tomography are increased in temporal lobe epilepsy. Ann Neurol 1988;23:231-7.

17 Crow TJ, Cross AJ, Johnstone EC, Owen F, Owens DGC, Waddington JL. Abnormal involuntary movements in schizophrenia: Are they related to the disease process or its treatment? Are they associated with changes in dopamine receptors? J Clin Psychopharmacol 1982;2:336-40.

18 Kornhuber J, Riederer P, Reynolds GP, Beckmann H, Jellinger $K$, Gabriel ZE. 3H-Spiperone binding sites in post-mortem brains from schizophrenic patients: relationship to neuroleptic drug treatment, abnormal movements, and positive symptoms. $J$ Neural Transm 1989;75:1-10.

19 Jenner P, Rupniak NMJ, Marsden CD. Differential alteration of striatal D1 and D2 receptors induced by the long-term ڤ administration of haloperidol, sulpiride or clozapine to rats. In: Casey DE, Chase TN, Christensen AV, et al eds. Dyskinesia Research and Treatment. Berlin: Springer, 1985:174-81.

20 Rupniak NMJ, Jenner P, Marsden CD. Acute dystonia induced by neuroleptic drugs. Psychopharmacology 1983;79:226-30.

21 Waddington JL, Cross AJ, Gamble SJ, Bourne RC. Spontaneous orofacial dyskinesia and dopaminergic function in rats after 6 months of neuroleptic treatment. Science 1983;220:530-2.

22 Smith JM, Baldessarini RJ. Changes in prevalence, severity and recovery in tardive dyskinesia with age. Arch Gen Psychiatry 1980;37:1368-73.

23 Wong DF, Wagner HN, Dannals RF, et al. Effects of age o dopamine and serotonin receptors measured by positro $\$$ tomography in the living human brain. Science 1984;22\% 1393-6.

24 Baron JC, Mazière B, Loc'h C, Sgouropoulos P, Bonnet AM, Agiĝ Y. Progressive supranuclear palsy: Loss of striatal dopamine receptors demonstrated in vivo by positron tomograph? Lancet 1985;i:1163-4.

25 Severson JA, Marcusson J, Winblad B, Finch CE. Age-correlate loss of dopaminergic binding sites in human basal ganglia. $\bar{\omega}$ Neurochem 1982;39:1623-31.

26 Morgan DG, Marcusson JO, Nyberg P, et al. Divergent changes in D1 and D2 dopamine binding sites in human brain during aging. Neurobiol Aging 1987;8:195-201.

27 Seeman P, Bzowej NH, Guan H-C, et al. Human brain dopamine receptors in children and aging adults. Synapse 1987;1: 399-404.

28 Tamminga CA, Thaker GK, Chase TN. GABA dysfunction in the pathophysiology of Tardive Dyskinesia. In: Casey DE, Chase TN, Christensen AV, et al eds. Dyskinesia - Research and Treatment. Berlin: Springer, 1985:122-7.

29 Gerlach J, Reisby N, Randrup A. Dopaminergic hypersensitivity and cholinergic hypofunction in the pathophysiology of tardive dyskinesia. Psychopharmacologia (Berl.) 1974;34:21-5.

30 Kaufmann CA, Jeste DV, Shelton RC. Noradrenergic and neuroradiological abnormalities in Tardive dyskinesia. Biol Psychiatry 1986;21:799-812.

31 Gunne LM, Häggström JE, Sjöquist B. Association with persistent neuroleptic-induced dyskinesia of regional changes in brain GABA synthesis. Nature 1984;309:347-9.

32 Casey DE. Behavioural effects of long-term neuroleptic treatment in Cebus monkeys. In: Casey DE, Chase TN, Christensen AV, et al eds.. Dyskinesia: Research and Treatment. Berlin: Springer, 1985:211-6.

33 Gunne LM, Häggström JE. Pathophysiology of Tardive dyskinesia. In: Casey DE, Chase TN, Christensen AV, et al eds. Dyskinesia: Research and Treatment. Berlin: Springer, 1985;191-3.

34 Burke RE. Tardive dyskinesia. Neurology 1984;34:1348-53.

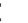

